\title{
DESAIN PHANTOM AIR UNTUK KALIBRASI CT NUMBER DAN KESERAGAMAN CT NUMBER PADA PESAWAT CT SCAN
}

\author{
A MODIFIED WATER PHANTOM DESIGN \\ FOR CT NUMBER CALLIBRATION AND UNIFORMITY
}

\author{
Ary Kurniawati ${ }^{1)}$, Cholid Badri $^{2}$, Jeffri Ardiyanto ${ }^{3)}$ \\ ${ }^{1,2,3)}$ Health Polytechnics of Semarang-Indonesia \\ e-mail : ary.kurniawati@yahoo.co.id
}

\begin{abstract}
Background: Callibration of CT number and uniformity is very important to the CT QC program particularly when the program aims to ensure that the CT Scanner equipment operates within the manufacturer's specifications. Since the commercial CT QC phantom is not always available or affordable in the department, a simple, easy and cheap modified CT water phantom design could be useful to support further regular departmental CT QC program.

Purpose: (1) to design , a simple and an easy to handle of the modified CT water phantom, and (2) to verify its callibration and measurement functions based on to the gold standard of a commercial CT water phantom.

Methods: This study is an experimental research laboratories, where a modified design of CT water phantom is then compared to the comercial gold standard CT water phantom. The commercial CT water phantom uses a cylindrical phantom that contains water with various diameter in sizes. In the modified CT phantom design, it filled with water as well, where the three different size in phantom diameters $(15 \mathrm{~cm}$, $20 \mathrm{~cm}$ and $32 \mathrm{~cm}$ recpectively) created for specific measurement purpose that of the CT Number and uniformity CT Number.

Results: Calliberating the function of the modified CT phantom design resulted in the three observasional data. For all different phantom diameters $(15,20$ and $32 \mathrm{~cm})$ showed some variation about their CT number and homogenity. Most of the callibration and homogenity tests of the CT number in water deemed significant (cal. CT number for the $20 \mathrm{~cm}$ and 32 diameter phantoms, $0,001<0,05$ and sig. $0,04<0,05$ respectively), instead of that the uniformity test of the phantom sized with $20 \mathrm{~cm}$ in diameter $(0,432>0,05)$.

Conclussion: A modified water CT phantom designed with $20 \mathrm{~cm}$ in diameter could be used for measurement of the CT number uniformity. Yet, measurements of the CT number callibration and uniformity needed to be consider againts from a failed measurement due to the phantom problem design with sizes at 20 and $32 \mathrm{~cm}$ in diameters.
\end{abstract}

Key Word: CT scanner; calibration phantom; CT number; uniformity CT number.

\section{PENDAHULUAN}

Computed Tomography (CT) Scan merupakan salah satu modalitas pencitraan diagnostik yang memanfaatkan teknologi komputer sebagai pengolah data sinar-X yang telah mengalami atenuasi dalam tubuh pasien yang diperiksa. Hasil atenuasi sinar-X ini dirubah menjadi data digital dalam skala Hounsfield Unit (HU) yang dikenal dengan CT number, kemudian ditampilkan di layar komputer dalam skala abu-abu. Skala ini menunjukkan udara dengan nilai CT number -1000 divisualisasikan dalam warna gelap, material dengan dua kali atenuasi (tulang) dengan nilai CT number +1000 divisualisasikan dalam warna terang dan air dengan nilai $C T$ number 0 ditampilkan dalam citra dengan warna pada titik tengah dari skala keabu-abuan.

Nilai HU ini sangat penting dalam aplikasi klinis CT scan untuk penegakan diagnosa, misalnya untuk mengetahui kelainan dari jaringan normal. Berbagai penelitian telah dilakukan, seperti penelitian yang dilakukan Davenport, M.S dan kawan-kawan (2011) yang bertujuan untuk menentukan ambang nilai HU yang optimal dan ukuran ROI yang dibutuhkan untuk mendiagnosis renal angiomyolipoma (renal AML) secara akurat dan membedakannya dengan renal cell carcinoma (RCC). Hasilnya, ambang atenuasi dari $-10 \mathrm{HU}$ atau lebih rendah, dengan menggunakan ukuran ROI 19 - 24 $\mathrm{mm}^{2}$ dapat membedakan RCC dengan renal AML dengan akurat (Devenport, 2011). Pooler, dkk (2012) melakukan penelitian untuk menganalisis nilai atenuasi dari patologis yang terbukti renal cell carsinomas (RCCs) pada unenhanced $C T$ dan untuk menentukan rentang nilai dimana keganasan harus dipertimbangkan. Hasilnya semua terbukti RCCs yang terdapat pada daerah substansial noncalcified, terukur 20 - 70 HU dengan ROI pada unenhanced CT. Lesi ginjal pada rentang ini dianggap ganas, sedangkan lesi yang berada di luar kisaran ini dapat dianggap jinak.

Dalam aplikasi yang lain nilai HU juga membantu keberhasilan pemeriksaan CT scan dengan menggunakan media kontras untuk meningkatkan kontras gambar pada organ yang diperiksa. Teknik bolus tracking digunakan untuk memperoleh waktu tunda yang optimal setelah media kontras diinjeksikan sebelum scaning dilakukan. Chan R, dkk (2011) melakukan penelitian untuk memperoleh waktu tunda fase arteri yang optimal sebelum melakukan scaning untuk mendeteksi focal liver lession menggunakan teknik bolus tracking. Hasilnya diperoleh opasitas yang lebih baik dari hepatocellular carcinomas selama fase arteri menggunakan teknik bolus tracking dengan waktu tunggu 6 detik dari abdominal aorta yang memiliki nilai ambang $100 \mathrm{HU}$.

Nilai HU juga digunakan sebagai acuan dalam pengukuran volume suatu objek. Nawaretne S, dkk (1997) 
melakukan penelitian untuk menentukan keakuratan estimasi volume menggunakan helical $C T$. Sepuluh pasien kanker discan dengan CT untuk menentukan ambang optimal atas dan bawah Hounsfield unit. Studi ini menunjukkan bahwa helical $C T$ adalah teknik yang sangat akurat untuk memperkirakan volume.

Pada CT scan, hasil gambar CT tidak terlepas dari artefak. Artefak dapat menurunkan kualitas gambar CT scan, kadang-kadang hasil gambar sampai tidak dapat digunakan untuk diagnosa. Pada CT Scan artefak didefinisikan sebagai pertentangan atau perbedaan antara rekonstruksi $C T$ number dalam gambar dengan koefisien atenuasi yang sesungguhnya dari obyek yang diperiksa. Artefak pada gambar CT berasal dari berbagai sumber, salah satunya artefak berbasis fisika hasil dari proses fisika akuisisi data CT.

Berkas sinar-X terdiri dari foton dengan berbagai energi, setelah melewati sebuah objek, foton ini menjadi "lebih keras" (beam hardening) dapat dikatakan terjadi kenaikan rata-rata energi sinar-X. Ada dua jenis artefak yang bisa muncul pada gambar dari efek ini, cupping artifacts dan streaks and dark band. Sinar-X yang melewati bagian tengah phantom silinder energinya menjadi lebih besar karena melewati lebih banyak bahan, karena energinya lebih besar, tingkat atenuasinya menurun sehingga intensitas sinar-X yang diterima detektor lebih besar. Oleh karena itu, profil atenuasi yang dihasilkan berbeda dari profil ideal yang diperoleh tanpa terjadinya beam hardening. Profil CT number dari phantom tampak seperti bentuk piala (bagian tepi lebih terang daripada bagian tengah) bila terdapat cupping artifact. Pada penampang melintang objek yang sangat heterogen, pita gelap atau goresan dapat muncul antara dua benda padat pada gambar. Hal ini terjadi karena bagian dari berkas sinar-X yang melewati salah satu objek pada posisi tabung tertentu terjadi peningkatan energi sinar-X. Artefak ini dapat terjadi pada daerah tulang atau pada saat menggunakan media kontras, artefak ini mungkin dapat menyebabkan kesalahan diagnosa penyakit pada objek di sekitarnya. Untuk mengurangi terjadinya beam hardening menggunakan filtrasi, koreksi kalibrasi dan beam hardening correction software. Kalibrasi dilakukan dengan menggunakan phantom berbagai ukuran, sehingga memungkinkan detektor melakukan kalibrasi dengan kompensasi toleransi untuk efek beam hardening dari ukuran pasien yang berbeda-beda[5]. Pengujian uniformity $C T$ number akan mendeteksi adanya efek beam hardening dari awal sebelum pemeriksaan.

Dalam siklus hidup peralatan medis menurut World Health Organization (WHO, 2003), fase utilisasi peralatan medis memerlukan perhatian khusus dari crinical engineer. Fase utilisasi peralatan medis berinteraksi dengan pengguna sehingga perlu dipantau kinerjanya untuk mengetahui nilai klinis dan efektivitas biaya, dengan menggunakan indikator kinerja seperti down time dan biaya siklus hidup. Peningkatkan mutu dan efektifitas dalam pelayanan serta keselamatan terhadap pasien (patient safety) dari penggunaan peralatan kesehatan sudah menjadi tuntutan dan kehendak masyarakat, oleh karena itu dibutuhkan suatu program pemeliharaan dan kalibrasi peralatan kesehatan secara periodik/berkala dan berkesinambungan. Hal ini diperlukan untuk menjamin dan menjaga kinerja peralatan kesehatan serta dapat diketahui kebenaran nilai keluarannya atau kinerjanya, siap dan laik pakai serta aman bagi pasien dan pengguna.

Menurut Undang-Undang Republik Indonesia nomor 44 tahun 2009 tentang Rumah Sakit peralatan medis harus memenuhi standar pelayanan, persyaratan mutu, keamanan, keselamatan dan laik pakai sehingga harus diuji dan dikalibrasi secara berkala. Pengujian dan kalibrasi ini bertujuan untuk memastikan kesesuaian karakteristik alat medis terhadap spesifikasi pabrikan, sehingga dapat diketahui kondisi perlatan medis agar tetap terjaga sesuai dengan spesifikasinya.

Sebagai salah satu alat penunjang diagnostik, kualitas gambar yang dihasilkan dan keakuratan diagnosa harus terjaga, sehingga diperlukan suatu program kontrol kualitas yang dilakukan secara berkala untuk mengetahui kinerja pesawat $C T$ scan. Salah satunya adalah kalibrasi nilai $C T$ number dan keseragaman CT number (flatness CT number). Uji kalibrasi $C T$ number ini merupakan prosedur harian rutin yang dilakukan sebelum pesawat $C T$ scan digunakan untuk pemeriksaan untuk memperoleh nilai HU yang sesuai dengan batas toleransi yang diperbolehkan. Hal ini sangat diperlukan dalam aplikasi klinis untuk diagnosa suatu kelainan, pengukuran $C T$ number digunakan untuk menentukan nilai HU dari suatu objek. Apabila nilai CT number pada air berubah, maka akan terjadi perubahan juga nilai $C T$ number pada material yang lain.

Pengujian CT number air ini dilakukan untuk memastikan peralatan $C T$ scan beroperasi sesuai dengan spesifikasi pabrik. Kemungkinan kesalahan nilai $C T$ number air yang melebihi rentang yang ditentukan oleh pabrik terjadi karena kesalahan kalibrasi algoritma dalam menghasilkan $C T$ number. Masalah ini perlu mendapatkan perhatian segera dari crinical engineer dan petugas proteksi radiasi. Bila nilai $C T$ number diluar kisaran rentang yang direkomendasikan harus segera dikoreksi untuk memastikan keakuratan gambar yang di tampilkan oleh CT scan.

Selain kalibrasi $C T$ number, pengukuran keseragaman CT number pada objek yang homogen (flatness $C T$ number) juga tidak kalah penting. Air merupakan media yang dapat dipergunakan sebagai landasan pengukuran, mengingat air mudah dijumpai, murah dan mudah diperoleh dalam kondisi murni tidak memiliki kandungan apapun. Apabila CT number pada seluruh phantom berbeda lebih dari $5 \mathrm{HU}$ dari rata-rata CT number yang telah diukur, maka gambar CT dikatakan tidak "rata/flat". Jika CT number di bagian tengah lebih tinggi daripada CT number di bagian tepi, terdapat cupping artefact pada gambar[8]. Kalibrasi menggunakan phantom berbagai ukuran memungkinkan detektor melakukan kalibrasi dengan kompensasi toleransi untuk efek beam hardening dari ukuran pasien yang berbeda-beda, sehingga artefak dari beam hardening dapat dikurangi.

Media yang digunakan untuk pengukuran $C T$ number adalah regio of interest (ROI) sehingga diperoleh nilai $\mathrm{HU}$. Menurut AAPM Report No.1 (1997) untuk melakukan kalibrasi $C T$ number dibutuhkan phantom yang berisi air. 
Phantom ini berbentuk silinder yang berisi air murni. Ukuran phantom ini disesuaikan dengan protokol pemeriksaan yang digunakan pada saat kalibrasi, kalibrasi untuk protokol kepala dewasa menggunakan phantom dengan ukuran diameter 20 $\mathrm{cm}$, sedangkan kepala anak-anak $15 \mathrm{~cm}$. Protokol abdomen (body) menggunakan phantom dengan diameter $32 \mathrm{~cm}$. Beberapa perangkat CT scan memiliki sirkuit elektronik yang mengkompensasi lebar intensitas sinar-X yang mengaktivkan detektor. Intensitas sinyal tergantung pada jumlah jaringan yang dilewati sinar-X sebelum mencapai detektor. Kompensasi yang tidak tepat dari jumlah sinar-X yang sampai detektor dapat menyebabkan hasil kalibrasi CT number mengalami penyimpangan.

Pada tahun 1970-an, CT scan pertama kali digunakan untuk pemeriksaan kepala saja. Teknologi CT scan berkembang sangat cepat. Secara klinis penggunaan $C T$ scan semakin luas, tidak hanya untuk pemeriksaan kepala, dapat juga digunakan untuk pemeriksaan seluruh tubuh, misalnya sistem pencernaan, tulang belakang, sistem vaskuler dan pemeriksaan-pemeriksaan lain. Penggunaan teknologi ini juga tidak hanya digunakan untuk pasien dewasa tetapi juga pasien anak-anak. Penggunaan $C T$ scan untuk anak-anak di wilayah Asia tahun 2009 adalah sebesar 12,2\% dari seluruh pasien $C T$ scan dan jenis pemeriksaan yang sering dilakukan adalah kepala (sebesar $75 \%$ dari seluruh pemeriksaan CT scan anak). Protokol pemeriksaan yang digunakan untuk anak-anak disesuaikan dengan berat badan dan ukuran pasien (Seeram, 2011).

Pada awal tahun 2013, jumlah rumah sakit umum di Indonesia mencapai 1.063. Jumlah tersebut mencakup rumah sakit umum milik pemerintah (725), swasta (200) dan BUMN (68). Dari sekian banyak rumah sakit yang memiliki pesawat CT scan sebanyak 337 rumah sakit yang tersebar di seluruh wilayah Indonesia (Kemenkes RI, 2013). Dari data tersebut menunjukkan banyaknya penggunaan pesawat $C T$ scan di Indonesia.

Perangkat $C T$ scan biasanya dilengkapi dengan phantom untuk kalibrasi $C T$ number, tetapi pada setiap pengadaan perangkat $C T$ scan belum tentu disertai dengan phantom dengan berbagai ukuran. Selama ini jarang di temukan phantom kalibrasi $C T$ number untuk protokol anak-anak dan protokol abdomen. Pada prosedur pengujian penerimaan pesawat CT scan yang baru (acceptance testing) dari berbagai merk pesawat juga membutuhkan phantom dengan berbagai ukuran diameter untuk pengujian keseragaman $C T$ number dan noise gambar. Penting untuk melakukan kalibrasi dengan phantom kepala anak dan dewasa maupun phantom abdomen untuk memastikan keakuratan gambar yang di tampilkan oleh CT scan untuk berbagai protokol, sehingga perlu dibuat phantom untuk kalibrasi $C T$ number dengan biaya yang relatif murah dan hasilnya sama dengan gold standar.

\section{METODE}

Penelitian ini merupakan penelitan eksperimental laboratorium. Penelitian ini dilakukan dengan beberapa tahap. Yang pertama tahap pembuatan phantom. Phantom dirancang dari bahan resin (plastik) yang bening dan mempunyai kerapatan rendah. Phantom berbentuk silinder bulat dengan ukuran diameter $32 \mathrm{~cm}, 20 \mathrm{~cm}$ dan $15 \mathrm{~cm}$ dengan tinggi masing-masing phantom $5 \mathrm{~cm}$. Sisi atas didesain dengan dua lubang kecil untuk tempat masuk dan keluarnya air. Bagian bawahnya di buat tempat pengait ke meja pemeriksaan.

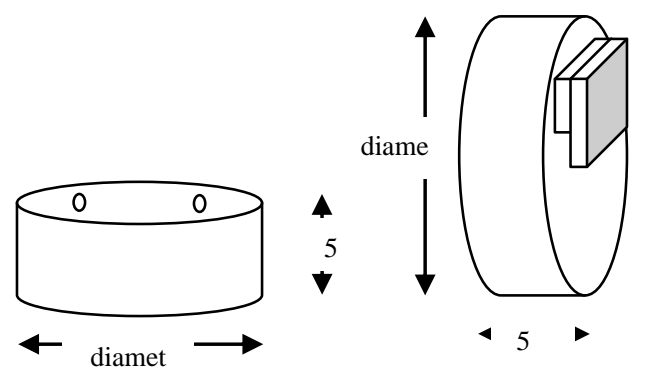

Gambar 1. Gambar desain phantom tampak dari depan dan belakang

Tahap selanjutnya adalah pengujian phantom. Pengukuran nilai $C T$ number dilakukan dengan menempatkan alat uji kalibrasi $C T$ number di atas meja scanner, kemudian atur alat sehingga berada pada pertengahan lampu indikator vertikal dan horisontal pada gantry. Scaning dilakukan untuk mendapatkan irisan axial di pertengahan phantom. Setelah muncul gambar di monitor dilakukan pengukuran nilai $C T$ number dengan menempatkan ROI sebesar 2-3 $\mathrm{cm}^{2}$ (200-300 $\mathrm{mm}^{2}$ ) dipertengahan phantom. Nilai yang diperoleh ini kemudian dicatat sebagai hasil pengukuran.

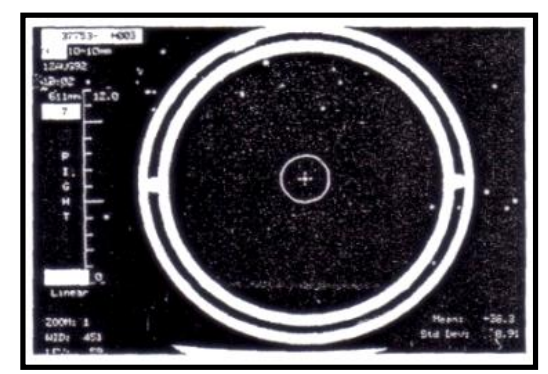

Gambar 2. Gambar peletakan ROI untuk pengukuran CT number

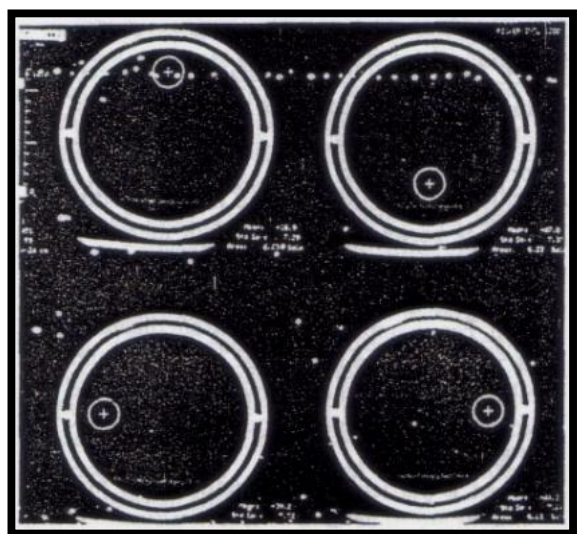

Gambar 3. Gambar penempatan ROI untuk pengukuran keseragaman CT number 
Pengukuran keseragaman $C T$ number dilakukan dengan cara menempatkan 4 ROI sebesar $2-3 \mathrm{~cm}^{2}\left(200-300 \mathrm{~mm}^{2}\right)$, yaitu pada posisi jam 12:00, 03:00, 06:00 dan 09:00 pada tepi gambar phantom. Keseragaman CT number diperoleh dari selisih nilai HU tertinggi pada posisi jam 12:00, 03:00, 06:00 dan 09:00 dengan nilai HU di tengah gambar phantom. Catat setiap hasil pengukuran.

Data yang telah terkumpul kemudian diolah dan dianalisis. Data yang telah terkumpul ini kemudian analisis untuk mengetahui apakah distribusi data normal atau tidak. Pengujian pertama untuk mengetahui perbedaan rata-rata nilai $C T$ number antara phantom buatan dengan phantom gold standar apabila data berdistribusi normal maka dilakukan uji independent $t$ test. Pengujian kedua untuk mengetahui perbedaan rata-rata nilai keseragaman $C T$ number antara phantom buatan dengan phantom gold standar apabila data berdistribusi normal maka dilakukan uji independent $t$ test. Apabila distribusi data tidak normal menggunakan uji statistik non parametrik dengan uji Man Whitney. Tingkat kepercayaan $95 \%(\alpha=0,05)$. Untuk pengambilan keputusan berdasarkan nilai probabilitas, yaitu jika probabilitas/Sig. > 0.05 maka $\mathrm{H}_{0}$ diterima dan jika nilai probabilitas/Sig. $<0.05$ maka $\mathrm{H}_{0}$ ditolak.

\section{HASIL}

Pada pembuatan phantom dipilih bahan dasar resin yang memiliki tingkat kerapatan yang rendah sehingga tidak menimbulkan artefak pada gambar yang dihasilkan. Resin dapat dibentuk sesuai model dan warnanya bening, sehingga mudah dilihat isi di dalamnya. Pemilihan bahan ini sesuai dengan ketentuan dari AAPM yang menyebutkan bahawa phantom untuk pengujian $C T$ number dan keseragaman $C T$ number terbuat dari resin atau plastik padat dengan bentuk silinder. Ketebalan wadah yang dibuat mengikuti ketentuan dari AAPM yaitu antara $0,5-1 \mathrm{~cm}$. Dua buah lubang dibuat pada bagian penutup atas untuk memasukkan air, penutup yang digunakan adalah mur-baut stainless tahan air. Tinggi phantom minimal $2 \mathrm{~cm}$, tetapi pada desain ini dibuat dengan tinggi $5 \mathrm{~cm}$ dengan alasan untuk menghindari mur-baut dari penutup agar tidak menimbulkan artefak pada gambar. Pengait dibuat dengan bentuk yang sederhana agar mudah dikaitkan dengan lengan alat kalibrasi.

Menurut AAPM isi dari phantom adalah air suling. Ada dua macam air dari proses penyulingan yaitu aqua-destilata dan aqua-bidestilata. Pada penelitian ini dipilih aqua-destilata karena mudah di dapat di pasaran dan harganya relatif lebih murah, walaupun kandungan mineral dalam aqua-destilata cenderung lebih banyak dari pada aqua-destilata yang dihasilkan dari proses destilasi bertingkat. Pengisian air ke dalam phantom dilakukan dengan cara memasukkan phantom ke dalam ember yang berisi air suling. Cara ini dipilih agar phantom tersisi penuh dengan air, tidak ada udara yang tertinggal di dalam phantom karena dapat menggangu hasil pengujian.

Pengujian pada phantom dengan ukuran diameter $15 \mathrm{~cm}$ menggunakan paramater sebagai berikut. Besarnya tegangan tabung $120 \mathrm{kV}$, arus tabung sebesar $100 \mathrm{~mA}$, waktu scan $1 \mathrm{~s}$, diameter Filed of View (FOV) $160 \mathrm{~mm}$, dan slice thickness 5 $\mathrm{mm}$. ROI yang digunakan untuk mendapatkan nilai HU dari phantom sebesar $224 \mathrm{~mm}^{2}$. Nilai HU dari hasil pengukuran phantom ukuran diameter $15 \mathrm{~cm}$ dapat dilihat pada tabel 1 .

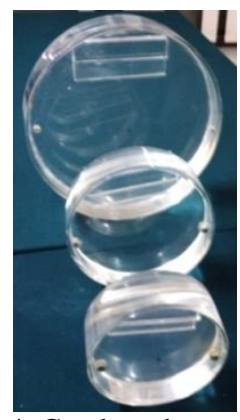

Gambar 4. Gambar phantom buatan

Tabel 1. Nilai HU pada phantom ukuran diameter $15 \mathrm{~cm}$

\begin{tabular}{ccc}
\hline $\begin{array}{c}\text { Pengukuran } \\
\text { ke- }\end{array}$ & $\begin{array}{c}\text { Nilai HU pada } \\
\text { pertengahan } \\
\text { phantom } \\
\text { buatan (TBN) }\end{array}$ & $\begin{array}{c}\text { Selisih nilai HU } \\
\text { pada phantom } \\
\text { buatan (SELBN) }\end{array}$ \\
\hline 1 & $-0,28$ & 4,20 \\
2 & $-0,13$ & 4,03 \\
3 & 0,15 & 4,03 \\
4 & 0,15 & 4,05 \\
5 & 0,20 & 4,13 \\
6 & $-0,05$ & 4,08 \\
\hline Rata-rata & 0,0067 & 4,07 \\
\hline
\end{tabular}

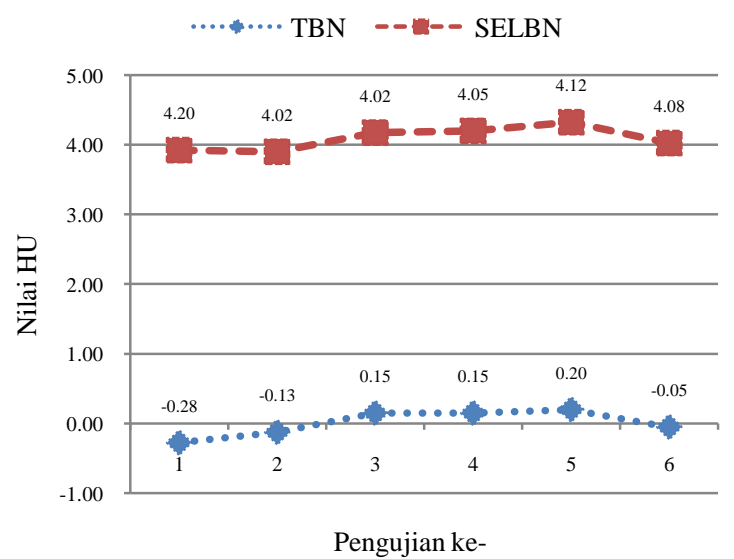

Gambar 5. Grafik hasil pengujian phantom buatan diameter $15 \mathrm{~cm}$

Hasil uji fungsi pada phantom buatan ukuran diameter $15 \mathrm{~cm}$ yang dilakukan sebanyak enem kali menunjukkan pada pertengahan phantom memiliki rata-rata nilai HU 0,0067 . Sebaran data yang tercatat masih berada pada rentang $0 \pm 7$ HU. Hal ini sesuai dengan ketentuan dari American College of Radiology Acceptance Criteria (ACR) yang menyebutkan bahwa toleransi nilai $\mathrm{HU}$ untuk air adalah $0 \pm 7 \mathrm{HU}$. Keseragaman $C T$ number yang diperoleh dari selisih nilai $\mathrm{HU}$ tertinggi pada posisi jam 12:00, 03:00, 06:00 dan 09:00 dengan tengah phantom pada phantom ukuran diameter $15 \mathrm{~cm}$ memiliki rata-rata 4,07 . Sebaran data yang tercatat masih 
berada pada rentang kurang dari $5 \mathrm{HU}$. Hal ini sesuai dengan ketentuan dari American College of Radiology Acceptance Criteria (ACR) yang menyebutkan perbedaan antara rata-rata CT number di tengah dan di tepi kurang dari 5 HU. Walaupun tidak dibandingkan dengan phantom gold standar, berdasarkan hasil uji fungsi di atas menunjukkan bahwa phantom buatan ukuran diameter $15 \mathrm{~cm}$ telah memenuhi kriteria dan dapat direkomendasikan untuk digunakan sebagai phantom pada kalibrasi $C T$ number dan keseragaman $C T$ number pada pesawat $C T$ scan. Phantom dengan ukuran diameter $15 \mathrm{~cm}$ biasanya digunakan kalibrasi pesawat CT untuk protokol kepala anak.

Pengujian pada phantom dengan ukuran diameter $20 \mathrm{~cm}$ baik phantom buatan maupun gold standar menggunakan paramater sebagai berikut. Besarnya tegangan tabung $120 \mathrm{kV}$, arus tabung sebesar $150 \mathrm{~mA}$, waktu scan $1 \mathrm{~s}$, diameter FOV $210 \mathrm{~mm}$, dan slice thickness $5 \mathrm{~mm}$. ROI yang digunakan untuk mendapatkan nilai HU dari phantom sebesar $256 \mathrm{~mm}^{2}$. Nilai HU dari hasil pengukuran phantom ukuran diameter 20 $\mathrm{cm}$ dapat dilihat pada tabel 2.

Pengujian pada phantom dengan ukuran diameter $32 \mathrm{~cm}$ baik phantom buatan maupun gold standar menggunakan paramater sebagai berikut. Besarnya tegangan tabung $120 \mathrm{kV}$, arus tabung sebesar $200 \mathrm{~mA}$, waktu scan $1 \mathrm{~s}$, diameter FOV $330 \mathrm{~mm}$, dan slice thickness $5 \mathrm{~mm}$. ROI yang digunakan untuk mendapatkan nilai HU dari phantom sebesar $256 \mathrm{~mm}^{2}$. Nilai HU dari hasil pengukuran phantom ukuran diameter 32 $\mathrm{cm}$ dapat dilihatt pada tabel 3.

Tabel 2. Nilai HU pada phantom ukuran diameter $20 \mathrm{~cm}$

\begin{tabular}{ccccc}
\hline \multirow{2}{*}{$\begin{array}{c}\text { Penguk } \\
\text { uran } \\
\text { ke- }\end{array}$} & $\begin{array}{c}\text { Nertengahan } \\
\text { phantom gold } \\
\text { standar } \\
\text { (TGS) }\end{array}$ & $\begin{array}{c}\text { Pertengahan } \\
\text { phantom } \\
\text { buatan } \\
\text { (TBN) }\end{array}$ & $\begin{array}{c}\text { Selisih } \\
\text { phantom } \\
\text { gold } \\
\text { standar } \\
\text { (SELGS) }\end{array}$ & $\begin{array}{c}\text { Selisih } \\
\text { phantom } \\
\text { buatan } \\
\text { (SELBN) }\end{array}$ \\
\hline 1 & 1,40 & 1,90 & 2,30 & 2,65 \\
2 & 1,35 & 2,13 & 2,85 & 2,13 \\
3 & 1,03 & 1,78 & 4,98 & 4,48 \\
4 & 1,10 & 1,75 & 3,65 & 2,45 \\
5 & 1,10 & 1,65 & 3,78 & 3,25 \\
6 & 1,65 & 1,68 & 3,15 & 3,25 \\
\hline
\end{tabular}

Tabel 3. Nilai HU pada phantom ukuran diameter $32 \mathrm{~cm}$

\begin{tabular}{ccccc}
\hline $\begin{array}{c}\text { Penguk } \\
\text { uran } \\
\text { ke- }\end{array}$ & $\begin{array}{c}\text { Nilai HU } \\
\text { pada } \\
\text { pertengahan } \\
\text { phantom gold } \\
\text { standar } \\
\text { (TGS) }\end{array}$ & $\begin{array}{c}\text { Nilai HU } \\
\text { pada } \\
\text { pertengahan } \\
\text { phantom } \\
\text { buatan } \\
(\text { TBN) }\end{array}$ & $\begin{array}{c}\text { Selisih } \\
\text { nilai HU } \\
\text { pada } \\
\text { phantom } \\
\text { gold } \\
\text { standar } \\
\text { (SELGS) }\end{array}$ & $\begin{array}{c}\text { Selisih nilai } \\
\text { HU pada } \\
\text { phantom } \\
\text { buatan } \\
\text { (SELBN) }\end{array}$ \\
\hline 1 & $-1,03$ & $-2,08$ & 6,18 & 5,78 \\
2 & $-1,25$ & $-1,73$ & 6,28 & 6,03 \\
3 & $-1,75$ & $-1,53$ & 5,78 & 6,03 \\
4 & $-1,13$ & $-1,93$ & 6,45 & 5,65 \\
5 & $-0,83$ & $-2,15$ & 6,88 & 5,43 \\
6 & $-1,60$ & $-2,20$ & 5,83 & 5,43 \\
\hline
\end{tabular}

Sebelum melakukan analisa lebih lanjut perlu diketahui apakah data yang tersedia terdistribusi secara normal atau tidak. Hasil uji normalitas pada phantom ukuran diameter 20 $\mathrm{cm}$ dan $32 \mathrm{~cm}$ dengan Kolmogorov-Smirnov nilai Sig > 0,05 pada semua data. Demikian juga nilai dengan Sahpiro-Wilk nilai Sig. > 0,05 pada semua data sehingga semua data berdistribusi normal.

Untuk melihat sejauh mana perbedaan rata-rata nilai HU antara phantom buatan dengan phantom gold standar, maka perlu dilakukan uji beda. Hasil uji normalitas data menunjukkan semua data berdistribusi normal sehingga uji beda yang digunakan adalah uji independent $t$ test. Tingkat kepercayaan 95\% $(\alpha=0,05)$. Untuk pengambilan keputusan berdasarkan nilai probabilitas, yaitu jika probabilitas/Sig. > 0.05 maka $\mathrm{H}_{0}$ diterima dan jika nilai probabilitas $<0.05$ maka $\mathrm{H}_{0}$ ditolak.

Pada hasil uji statistik Independent t-test phantom ukuran diameter $20 \mathrm{~cm}$ menunjukkan adanya perbedaan pengukuran nilai HU air pada uji kalibrasi CT number antara phantom buatan dengan phantom gold standar (Sig. $0,01<0,05)$. Begitu juga hasil pengujian pada phantom ukuran diameter $32 \mathrm{~cm}$ menunjukkan adanya perbedaan rata-rata nilai HU air pada uji kalibrasi CT number antara phantom buatan dengan phantom gold standar (Sig. 0,04<0,05). Namun apabila dilihat dari nilai rata-rata $C T$ number pada phantom buatan dan gold standar tidak jauh berbeda.

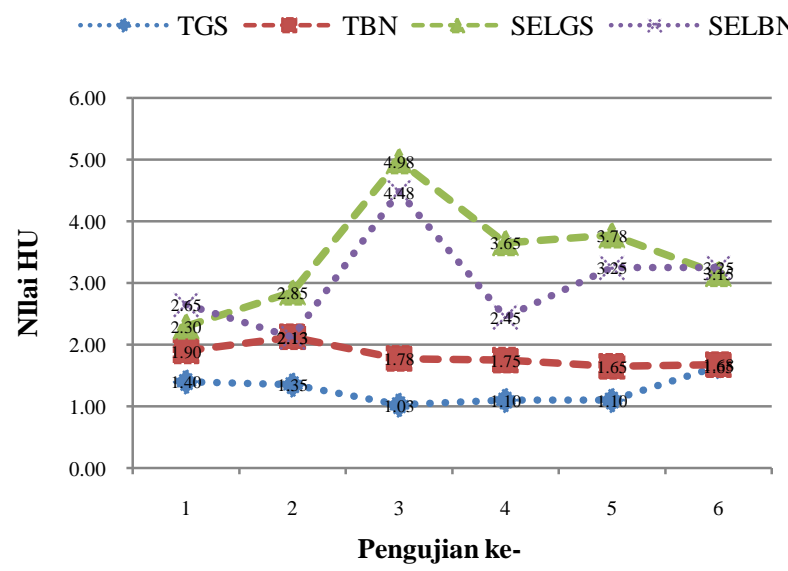

Gambar 6. Grafik hasil pengujian phantom ukuran diameter $20 \mathrm{~cm}$

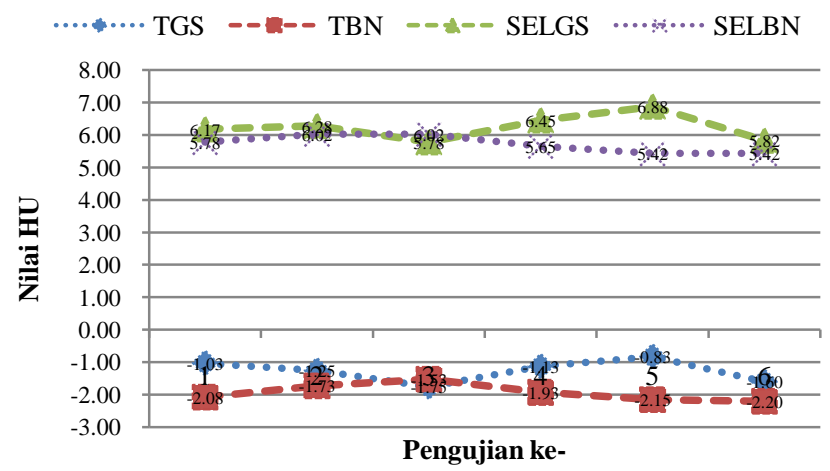

Gambar 7. Grafik hasil pengujian phantom ukuran diameter $32 \mathrm{~cm}$ 
Pada phantom dengan diameter $20 \mathrm{~cm}$ rata-rata nilai $\mathrm{HU}$ phantom gold standar adalah 1,2717 dengan standar deviasi 0,23794 sedangkan phantom buatan memiliki rata-rata nilai HU 1,8150 dengan standar deviasi yang lebih rendah yaitu 0,17740 . Pada phantom dengan diameter $32 \mathrm{~cm}$ rata-rata nilai HU phantom gold standar adalah -1,250 dengan standar deviasi 0,34939 sedangkan phantom buatan memiliki rata-rata nilai HU -1,9367 dengan standar deviasi yang lebih rendah yaitu 0,26212 .

\section{PEMBAHASAN}

Menurut teori, apabila CT scanner berada pada performa yang baik maka seharusnyna nilai HU air yang diperoleh adalah pada rentang $0 \pm 7$ HU. Nilai tersebut merupakan nilai toleransi terhadap nilai HU air. Sebaran data yang tercatat pada phantom buatan maupun ukuran diameter $20 \mathrm{~cm}$ dan 32 $\mathrm{cm}$ masih berada dalam rentang $0 \pm 7 \mathrm{HU}$. Penelitian menggunakan alat uji buatan mampu menampakkan kinerja pesawat $C T$ scan tidak jauh berbeda dengan yang dilakukan bila menggunakan phantom gold standar. Artinya phantom buatan memiliki nomor atom dan ketebalan bahan serta komposisi air hampir sama dengan yang ada pada phantom bawaan pesawat $C T$ scan.

Keseragaman CT number ini dilihat dari selisih nilai HU tertinggi di bagian tepi dan tengah phantom. Hasil uji perbandingan rata-rata dua sampel dengan uji Independent $t$ test keseragaman $C T$ number menunjukkan tidak terdapat perbedaan yang signifikan pada pengukuran keseragaman (uniformity $C T$ number) antara phantom buatan dengan phantom gold standar. Pada phantom ukuran diameter $20 \mathrm{~cm}$ dengan nilai Sig. 0,432 >0,05. Artinya, besarnya rata-rata selisih nilai HU tertinggi antara bagian tepi dan tengah pada phantom buatan dan phantom gold standar secara signifikan tidak berbeda.

Sedangkan pada phantom ukuran diameter $32 \mathrm{~cm}$ nilai Sig. $0,30<0,05$. Artinya terdapat perbedaan rata-rata selisih nilai HU tertinggi antara bagian tepi dan tengah pada phantom buatan dan phantom gold standar. Apabila dilihat dari ratarata selisih nilai HU tertinggi pada tepi dan tengah phantom ukuran diameter $32 \mathrm{~cm}$, phantom gold standar memiliki nilai HU 6,2333 yang lebih tinggi dari pada phantom buatan yang memiliki rata-rata selisih nilai HU 5,7250. Standar deviasi nilai HU phantom gold standar juga lebih besar yaitu 0,40947 dari pada phantom buatan yaitu 0,27157 . Dilihat dari nilai tersebut phantom buatan memiliki keceragaman $C T$ number yang lebih baik dibandingkan phantom gold standar.

Berdasarkan American College of Radiology Acceptance Criteria (ACR), nilai HU yang diperoleh dari selisih nilai HU di bagian tepi dan tengah phantom $<5$ HU maka hal ini menunjukkan bahwa performa $C T$ scanner berada dalam kondisi yang baik. Nilai tersebut merupakan toleransi terhadap keseragaman suatu bidang/material yang homogen. Sebaran data nilai selisih nilai HU tertinggi di bagian tepi dan tengah phantom pada phantom ukuran diameter $20 \mathrm{~cm}$ baik gold standar maupun buatan menunjukkan $<5 \mathrm{HU}$, sehingga masih memenuhi standar dari ACR.
Menurut International Atomic Energy Agency (IAEA) perbedaan nilai $\mathrm{HU}$ antara bagian tepi dan tengah objek yang homogen harus $<8 \mathrm{HU}$. Sedangkan sebaran data pada phantom ukuran diameter $32 \mathrm{~cm}$ baik gold standar dan buatan menunjukkan lebih dari $5 \mathrm{HU}$ tetapi masih di bawah $8 \mathrm{HU}$, sehingga masih sesuai standar dari IAEA. Dalam hal ini, phantom buatan dapat memperlihatkan kinerja pesawat $C T$ scan yang lebih baik dari pada menggunakan phantom gold standar. Keseragaman nilai HU tergantung pada stabilias komposisi air dalam phantom, apabila komposisi air berubah dalam rentang waktu tertentu, maka $C T$ number yang dihasilkan juga akan berubah. Untuk mengatasi perubahan komposisi air di dalam phantom, dilakukan penggantian isi phantom dengan air yang baru saat akan digunakan.

Dari hasil pengujian nilai HU pada phantom dengan ukuran diameter $15 \mathrm{~cm}, 20 \mathrm{~cm}$ dan $32 \mathrm{~cm}$ baik phantom gold standar maupun phantom buatan menunjukkan pesawat $C T$ scan merk Thosiba yang dimiliki Instalasi Radiologi RSUD Goeteng Tarunadibrata Purbalingga memiliki kinerja yang bagus. Menurut ACR pesawat CT scan dalam performa yang bagus apabila sebaran nilai $\mathrm{HU}$ yang diperoleh pada rentang 0 \pm 7 HU. Menurut IAEA perbedaan nilai HU antara bagian tepi dan tengah objek yang homogen harus $<8 \mathrm{HU}$, hasil pengujian menunjukkan selisih tertinggi nilai HU antara bagian tengah dan tepi phantom sebarannya $<8 \mathrm{HU}$. hai ini juga menunjukkan pesawat $C T$ scan dalam performa yang bagus.

Pengujian nilai HU dan keserahaman nilai HU ini bertujuan untuk memastikan kesesuaian karakteristik alat medis terhadap spesifikasi pabrikan, sehingga dapat diketahui kondisi perlatan medis agar tetap terjaga sesuai dengan spesifikasinya. Dengan diketahuinya pesawat $C T$ scan dalam performa yang bagus dapat mewujudkan pengoperasian peralatan medis yang andal dan aman bagi pasien, pekerja dan masyarakat. Pemeliharaan yang mendasar dan strategi kalibrasi secara berkala juga membantu meningkatkan efisiensi pengelolaan peralatan medis dari waktu ke waktu, peningkatan efisiensi dapat mengurangi resiko penggunaan peralatan medis secara keseluruhan (Dyro, 2007).

Peningkatkan mutu dan efektifitas dalam pelayanan serta keselamatan terhadap pasien (patient safety) dari penggunaan peralatan kesehatan sudah menjadi tuntutan dan kehendak masyarakat. Oleh karena itu dibutuhkan suatu program pemeliharaan dan kalibrasi peralatan kesehatan secara periodik/berkala dan berkesinambungan untuk memastikan bahwa perangkat tetap berfungsi dalam batas-batas yang dikenakan oleh kriteria uji. Di sinilah peran soerang cilinical engineering dalam siklus hidup peralatan medis pada fase utilisasi/penggunaan dan perawatan peralatan medis.

\section{SIMPULAN}

Pada penelitian ini telah dibuat phantom buatan dengan bahan dasar resin dengan kerapatan rendah, mudah dibentuk dan warnanya bening. Phantom dibuat dengan bentuk silinder dengan diameter $15 \mathrm{~cm}, 20 \mathrm{~cm}, 32 \mathrm{~cm}$ dan tinggi $5 \mathrm{~cm}$ kemudian phantom diisi dengan aqua-destilata. Hasil uji beda nilai CT number air pada phantom gold standar dan phantom 
buatan menunjukkan terdapat perbedaan pada pengukuran nilai HU air pada uji kalibrasi CT number antara phantom buatan dengan phantom gold standar. Pada phantom ukuran diameter $20 \mathrm{~cm}$ nilai Sig. $0,001<0,05$, phantom ukuran diameter $32 \mathrm{~cm}$ nilai Sig. $0,04<0,05$. Hasil uji beda keseragaman CT number pada phantom buatan dan phantom gold standar ukuran diameter $20 \mathrm{~cm}$ menunjukkan tidak terdapat perbedaan yang signifikan antara phantom buatan dengan phantom gold standar, nilai Sig. 0,432 > 0,05. Pada phantom ukuran diameter $32 \mathrm{~cm}$ menunjukkan terdapat perbedaan yang antara phantom buatan dengan phantom gold standar, nilai Sig. $0,030<0,05$.

\section{DAFTAR PUSTAKA}

Barrett, J.F, dkk. 2007. Artifact in CT: Recognition and Avoidance. RSNA.

Chan R, dkk. 2011. Optimising the scan delay for arterial phase imaging of the liver using the bolus tracking technique. Malaysia.

Davenport, M.S, dkk. 2011. Angiomyolipoma with Hounsfield Unit Thresholds: Effect of Size of Region of Interest and Nephrographic Phase Imaging. RSNA.

Dyro, Joseph F. 2007. The Clinical Engineering Handbook, The Biomedical Engineering Series.

Kemenkes RI. 2013. Data Rumah Sakit On Line. Kementrian Kesehatan Republik Indonesia - Direktorat Jenderal Bina Upaya Kesehatan, 2013.

Nawaratne S, dkk. 1997. Accuracy of volume measurement using helical CT. Australia.

Pooler DB, dkk. 2012. Renal Cell Carsinoma: Attenuation values on unenhanced CT. Department of Radiology, University of Wisconsin School of Medicine and Public Health Madison, USA.

Seeram, E. 2011. Computed Tomography : Physical Principles, Clinical Applications and Quality Control. Second Edition. W.B. Saunders Company : USA.

Undang-Undang RI no.44 tahun 2009 tentang Rumah Sakit

Vassileva, J, dkk. 2011. IAEA Survey of pediatric CT practice in 40 Countries in Asia, Europe, Latin America, and Africa: Part 1. Frequency and Appropriateness, American Roentgen Society.

WHO. 2003. Medical Device Regulations: Global overview and guiding principles. World Health Organization, Geneva. 